\title{
Application of Green Finance Tools in the System of Sustainable Interaction Between the Real and Financial Economy: Opportunities and Prospects
}

\author{
Joanna Koczar \\ Wroclaw University of Economics \\ Wroclaw, Poland \\ joanna.koczar@ue.wroc.pl \\ Madina Agliullina \\ Kazan (Volga region) Federal University \\ Kazan, Russia \\ madina.agliullina18@gmail.com
}

\author{
Venera Vagizova \\ Kazan (Volga region) Federal University \\ Kazan, Russia \\ venera.vagizova@mail.ru \\ Zarina Agliullina \\ Kazan (Volga region) Federal University \\ Kazan, Russia \\ zarinaagliullina18@gmail.com
}

\begin{abstract}
The article represents the algorithm of using green finance tools in financial design which allows to recognize the interaction between financial and real sectors of the economy in the system of sustainable development. Nowadays green finance is an important part of global financial system. This is due to focusing on investment in projects for environmentally sustainable development and contributing to the realization of low-carbon technologies. Formation of an independent direction of investment activity (green finance) is considered by experts as "one of the fundamental changes within the existing global financial system", aimed at ensuring sustainable growth in relation to solving social and environmental problems. In the article analytical methods of the green finance market structure investigation, comparative assessment of the development of these technologies between different economies are used. The article suggests an algorithm for combining the life cycle of the clean transport project with the stages of its financing. The results of the research can be applied in the system of determining financial institutions that are able to provide investments to the green projects in the fields of real sector economy
\end{abstract}

Keywords: green finance, investment technology, sustainability, green finance market analysis, industry classification of projects with a "green" character, an algorithm for financing the project's life stages

\section{INTRODUCTION}

Nowadays green finance is an important part of global financial system. This is due to focusing on investment in projects for environmentally sustainable development and contributing to the realization of low-carbon technologies.
Formation of an independent direction of investment activity (green finance) is considered by experts as "one of the fundamental changes within the existing global financial system", aimed at ensuring sustainable growth in relation to solving social and environmental problems. Available financial tools are expected to become the main mechanisms for the implementation of the UN Agenda for Sustainable Development for the period up to 2030. The necessity to integrate its goals into national development programs is recognized as one of the most important strategic priorities by the leading countries of the world. The idea of a green financial system is consistent with the concept of sustainable development and becomes its integral part.

\section{METHODS}

There is no general definition of the term "green finance". Some experts consider this concept as "synonymous with investment in environmentally sustainable development projects and the production of environmentally friendly goods and services", including reducing greenhouse gas emissions and measures to adapt to climate change.

Most experts stick to the point of view, according to which green financing should be understood primarily as investment activity. In this regard, the basic definition proposed by the G20 studying the Green Finance Study Group(GFSG) in 2016 can be considered as "investment that provides environmental benefits in the broad context of environmentally sustainable development".

In a broad sense, green finance means financial tools whose aim is to raise funds to solve environmental, resource 
and climate problems, as well as the appropriate infrastructure, including financial institutions and incentive mechanisms.

TABLE I. InSTITUTIONAL STRUCTURE OF THE GREEN FINANCING MARKET [1]

\begin{tabular}{|l|l|}
\hline $\begin{array}{c}\text { Green funding market } \\
\text { Participants }\end{array}$ & \multicolumn{1}{c|}{ Composition } \\
\hline Financial institutions & $\begin{array}{l}\text { State and public organizations; } \\
\text { Banks (global and national development } \\
\text { banks, commercial and state owned national } \\
\text { banks) } \\
\text { Funds (national, specialized) } \\
\text { Insurance companies }\end{array}$ \\
\hline \multirow{5}{*}{ Financial tools } & $\begin{array}{l}\text { Green bonds, green lending, guarantees for } \\
\text { financing green projects, state-owned green } \\
\text { funds, grants, loans, } \\
\text { Green insurance tools, green venture funds } \\
\text { Indices, pollution allowances }\end{array}$ \\
\hline \multirow{5}{*}{$\begin{array}{l}\text { Infrastructure } \\
\text { service organizations }\end{array}$} & $\begin{array}{l}\text { Organizers of the auction } \\
\text { Multifunctional trading platforms } \\
\text { Crowdfunding platforms } \\
\text { Rating agencies } \\
\text { Verifiers } \\
\text { Certification agencies } \\
\text { Research institutes }\end{array}$ \\
\hline
\end{tabular}

Currently the emergence of the global market for green financial instruments as a new component of the global financial system can be discussed. The features of this market are:

- combining various types of financial instruments (green funds, green banks and loans, green bonds, etc.),

- target use, i.e. ensuring the function of the transfer of capital from the financial sector to the real one for the realization of specific green programs, both at the state and corporate levels.

The implementation of global and regional green programs requires large financial investments. After the global financial and economic crisis of 2008-2009, a huge pressure influenced state budgets that prevented the expansion or at least the preservation of environmental protection expenses at the same level. For example, in the early 2010s, energy subsidies in developing countries was 480 billion dollars per year (this represents $26 \%$ of the total amount of public domestic finances), while for developed countries the same rate was 1.9 trillion dollars annually.

UN experts asses global demand for green investment at about 22 trillion dollars. It can be satisfied due to the diversion and redirection of excess financial resources, forming an overconcentration of fictitious capital and the emergence of economic bubbles in stock markets from the financial sector of the economy to the real one. According to scientists, the volume of global resources through the concept of creation of global imbalances is approximately 93 trillion dollars, or $30.5 \%$ of global financial assets.

More attention is being paid to the development of green finance in developing countries with emerging financial markets: in China, Brazil, India, South Africa, Indonesia,
Mongolia, Bangladesh, Colombia, Peru, Kenya and Vietnam. The active part of these countries in the globalization of green finance is due to three reasons:

- these states seek to immediately create a financial infrastructure that satisfies the modern requirements of environmentally and socially responsible investment at the very beginning of the processes of the greening global finance, i.e., to upgrade the financial market in accordance with new trends;

- the above-mentioned countries are faced with serious environmental problems due to the long-term development of outsourcing (the transfer of the production parts from developed countries);

- developing countries find their niche in the international financial system and seek to create new advantages on the way to getting rid of the status of "peripheral" sections in the global economy.

A significant tool of the green financing are green bonds $[2,3]$. The green bond is a debt security issued for the purpose of investing in projects related to environmental protection [4].

According to the Cbonds glossary, a bond can be considered "green" if the following conditions are met [5]:

1) funds raised during the emission are directed to projects that aim at introducing renewable energy sources, increasing energy efficiency, preserving biodiversity, combating environmental pollution, etc.,

2) the investment must comply with environmental principles, that is, the specific benefits to the environment through the implementation of a project attracting funding must be described, evaluated and periodically measured, as far as is possible,

3) funds raised must be used exclusively for the needs of the project declared for the issue of bonds, and the issuer spends these funds subject to mandatory disclosure,

4) the unspent balance of the issue of securities is subject to mandatory public disclosure at least once a year.

It should be noted that the government plays a key role in implementing measures to adopt the best available technologies and create a favorable investment climate in the market for green financial tools: it is necessary to create conditions under which the corporate sector is willing to sacrifice short-term benefits for long-term prosperity.

The main measures of government support for the market of green financing are the following:

- ensuring the integrity of the market. Forming the principles and standards of green bonds at the national level ensures the development of a reliable green market, guarantees government support for the green bond issues and helps investors to control the level of investment impact on the climate change;

- strategic bond issues. The implementation of issuing green bonds by the government to provide liquidity in the market, to attract and train investors. For these 
- obligations to disclose information (the minimum set of information published annually includes a list of environmental projects with their brief description, the amount of investments made and the predicted result).

To facilitate the certification of securities as green ones, the GBP standard also provides for the basic industry classification of projects for which financing can be attracted.

TABLE II. SECTORAL CLASSIFICATION OF PROJECTS ACCORDING TO GBP STANDARDS

benefits: environment-related taxes and charges, government guarantees, subsidy, direct government funding at the preparation stage, project design, government insurance, etc;

- guarantee of demand. Guaranteed demand through public procurement with a priority of environmental components.

The role of exchanges in the development of the green finance market should also be noted. Foreign stock exchanges support the market for green financing by creating a separate green stock exchange, a separate green section or a list of green bonds. According to CBI, green bond issues have been allocated on 10 foreign stock exchanges, including the Luxembourg Stock Exchange, the London Stock Exchange, the Oslo Stock Exchange, the Australian Stock Exchange, the New York Stock Exchange (NYSE), the Hong Kong Stock Exchange, and others.

Being a result of the international development banks' first issues, the green bond market appeared in 2007-2008. From 2007-2010, the main issuers of green bonds were the International Bank for Reconstruction and Development, the European Investment Bank, as well as some other regional and national development banks funds.

In 2014 the consortium of investment banks, such as Merrill Lynch, Citi, Crédit Agricole, JPMorgan Chase, BNP Paribas, Daiwa, Deutsche Bank, Goldman Sachs, HSBC, Mizuho Securities, Morgan Stanley, Rabobank and SEB developed Green Bonds Principles (GBP). GBP are accepted standards, followed by the majority of global green bond issuers.

Compliance with the GBPs guarantees investors that the issuer meets certain standards in terms of where the funds from the bonds go, how projects are selected and what reports are provided to investors. The GBP are international principles.

Through the GBP model were formulated four basic principles of the emission of green bonds:

- earmarked funds raised (must be recorded in the legal documentation of the issue);

- transparency of the choice and a specific environmental project evaluation for which funds are raised (all stages of this process should be reflected in the prospectus);

- a special procedure for managing fiscal revenue (funds are distributed on a separate account, the procedure for reporting on their spending is established);

\section{Projects categories}

Usage of renewable energy sources (including its production, transmission and equipment necessary for this);

Optimization of energy consumption (energy savings in construction industry, energy storage systems, heat supply, smart grids, appliances and equipment);

Pollution prevention and emission control (water waste treatment, control of greenhouse gas emissions, land reclamation, waste processing with the production of energy and new products, environmental monitoring);

Natural resources management (including the development of agriculture, fisheries, aquaculture, forestry, investment in "smart farming");

Biodiversity conservation;

Water management (including the development of infrastructure to provide the population with drinking water, drainage systems and sanitation, work on regulating river beds, countering floods);

"Clean" transport (electric and hybrid engines, rail and non-motorized transport, development of infrastructure for environmentally friendly vehicles, reduction of emissions);

Adaptation to climate change (including information support systems, surveillance and early warning systems);

Green technologies and solutions for production processes

\section{RESULTS}

Below, fig. 1 and fig. 2 graphically show the process of involving and using green bonds, as well as the content of the main stages of the project implementation on the example of the "clean transport" project. 


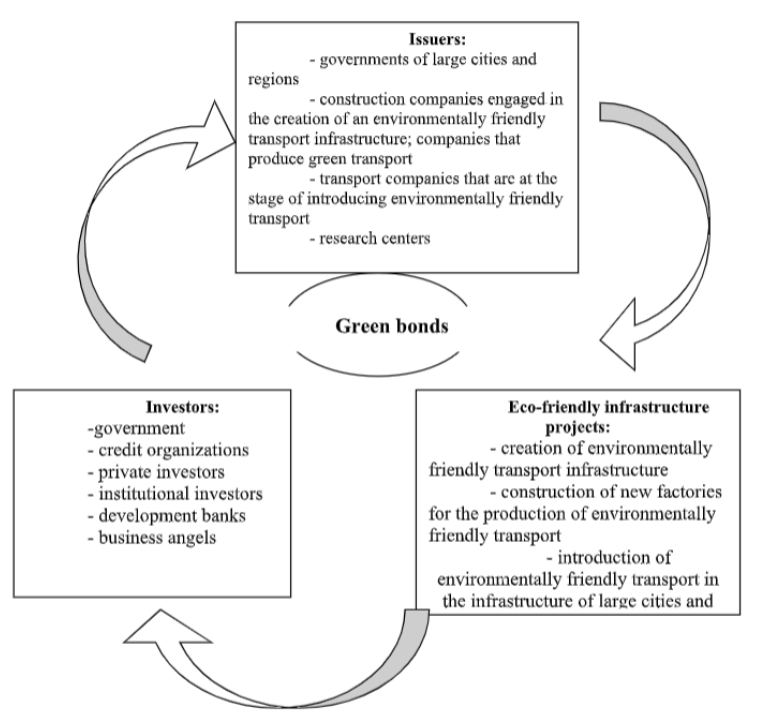

Fig. 1. The process of involving and using green bonds in the "clean" transport project

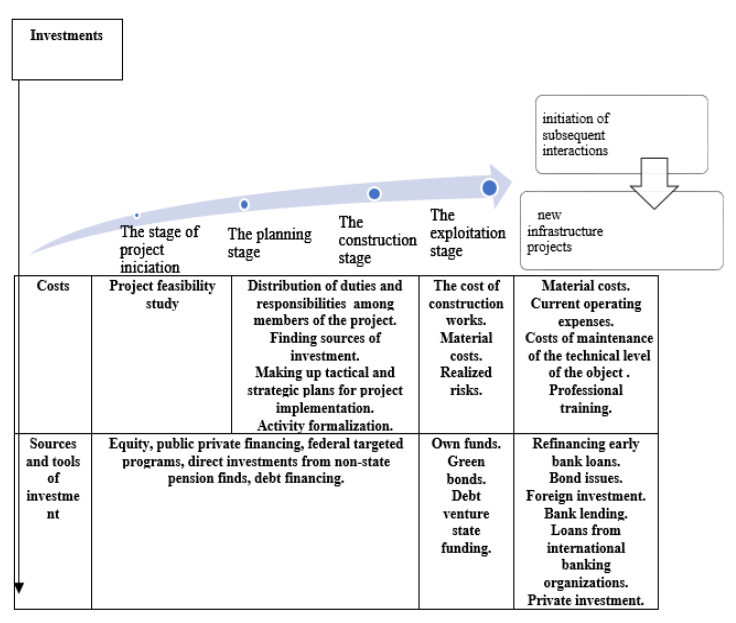

Fig. 2. Stages of the investment in infrastructure projects "clean" transport

Infrastructure projects consist of several stages, each of which represents a certain combination of investments in the risk-profit system and requires a different degree of government participation, capital markets and private investors. To attract "green" investments, cover risks and generate profits at each of these stages, a certain combination of investment tools is required.

It seems promising to build an effective mechanism for investing in transport infrastructure; the main goal of which is to develop a sustainable interaction between transport infrastructure entities at the stages of the infrastructure project life cycle. This mechanism will speed up the process of integrated development of "green" infrastructure.

Multiplicative effect becomes possible because of the complex influence of investment mechanisms on each stage of the infrastructure project life cycle. A positive result of this effect is considered to be achieved if, in the case of an infrastructure project, it leads to the formation of a favorable environment for the implementation of new "green" projects.

Despite the fact that following the Principles is voluntary, there is a consistent increase in their recognition in the world: as for July 2018, 178 issuers, investors and underwriters (in 2016- 117 people).

The global ecobond market also demonstrates high growth rates. At the end of 2017, its volume increased over 163 billion dollars, having increased more than $60 \%$ compared to 97.3 billion in 2016 .

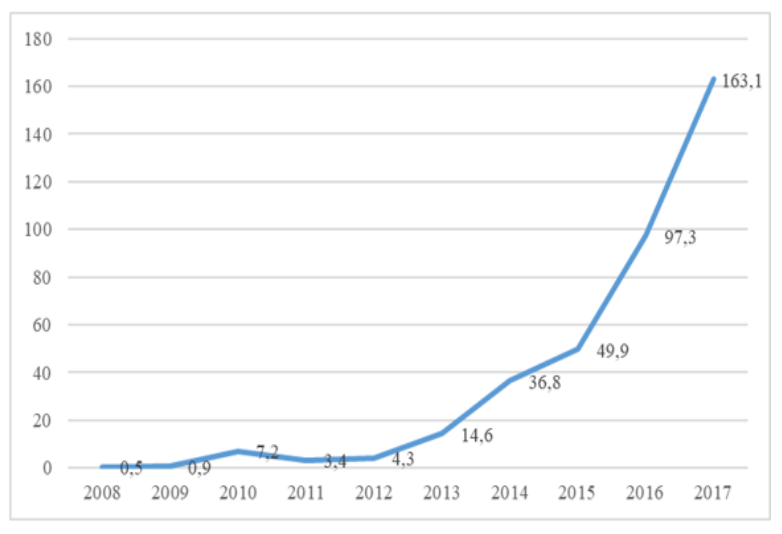

Fig. 3. The emission of green bonds in 2008-2017, billion US dollars [6]

According to the figure above the development of the first GBP had a great influence on the development of the ecobond market standard in 2014. It has become one of the main factors of its transition to the phase of dynamic growth, which has been steadily continuing over the past three years. The creation in a number of countries own methodological recommendations on the organization of the placement of green bonds on the basis of the GBP had a significant value in 2015-2017.

According to OECD experts, the following factors seem to be effective for production [7]:

- reputational benefits that allow the issuer to demonstrate its commitment to the principles of sustainable development and increase the attractiveness of the company's projects for investors;

- necessity for diversify the investor base.

In addition to expanding funding sources, it also helps to reduce the risks associated with possible changes of the demand for bonds in the longer term.

Involving institutional investors (pension funds, insurance companies, wealth management funds, etc.), most of which, as experience has shown, prefer to keep the purchased bonds until maturity, allows minimize the volatility of ecobond on the secondary market.

Furthermore, the demand for green bonds was experienced to outscrip their supply significantly and nowadays makes it possible for issuers to increase the volume of issues.

At the same time, the survey on the topic of the main challenges for the development of ecobond, conducted by the 
Group, studying the Green Finance in 2017 among issuers, investors and intermediary organizations, showed that there are barriers to market entry.

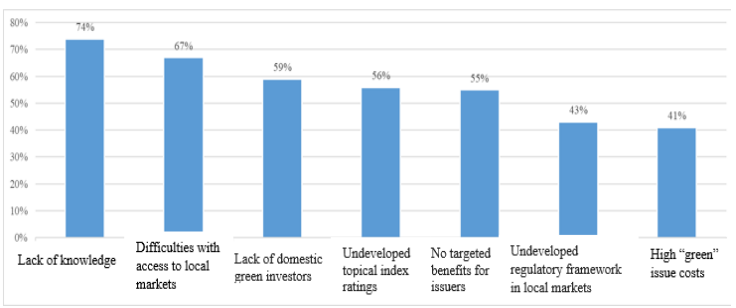

Fig. 4. Major obstacles to the development of the green bond market (according to the GFSG survey), \% [8]

Separately worth noting the problem of the profitability of green securities. When placing new issues of ordinary debt (plain vanilla bonds), issuers, aimed to attract investors, as a rule, offer a slightly higher yield compared to bonds circulating in the secondary market, taking into account the corresponding additional costs. Meanwhile, the question of whether this principle is maintained for green bonds remains debatable.

Comparing traditional bonds, the green securities are characterized by a longer circulation period. For example, in the corporate sector in France, $2 / 3$ ecobond issues have a maturity of $10-15$ years, which exceeds the corresponding figure for ordinary securities of the same issuers. A number of companies and banks (Neoen, Credit Agricole CIB) successfully place 15 - and 20-year ecobond.

Issues carried out within the public sector are characterized by longer periods. In 2017, the French state company SNCF, controlling railways, issued 30-year green bonds, while the French government issued 22-year bonds. Moreover, the practice of placing perpetual bonds is still developing. A large energy and gas company Engie released them in 2017. Similar trends were noticed on the markets of some other developing countries.

Currently, about $70 \%$ of all issues are accounted by international development banks, such as the World Bank, the Investment Bank of North Europe, the European Investment Bank, etc. Corporate issues represent about $20 \%$ of all issues. About $10 \%$ of issues is for governments and municipalities.

Issues in the total amount of $\$ 155.5$ billion were held in 2017. Only about $13 \%$ of them represented the development banks, $17 \%$ - government issues, and other $70 \%$ were issued by corporations. Sovereign issues opened a new period in the development of the green bond market in 2016, which has increased mainly due to development banks.

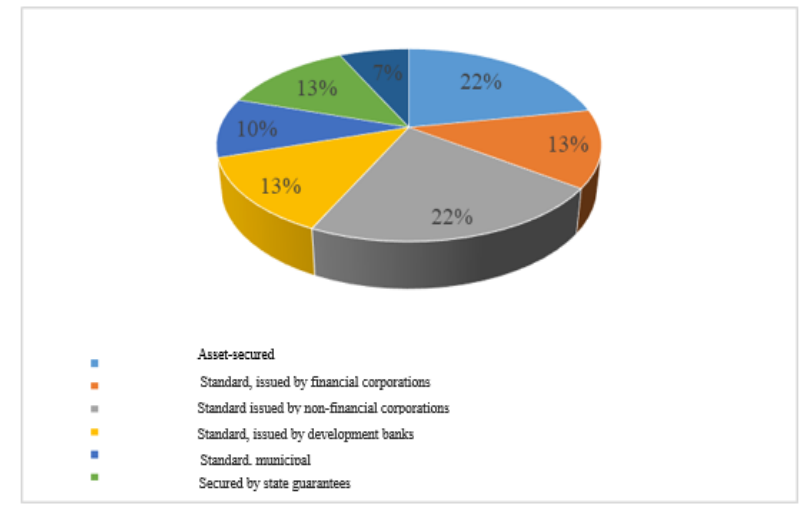

Fig. 5. The volume of green bond issues in 2017 by securities type, \% [9]

The People's Republic of China issued sovereign bonds in a record volume of a single issue for 3 billion dollars in 2016. In 2017, France issued sovereign green bonds with a value of 10.7 billion euros. The sovereign issues of Fiji and Nigeria amounted to 50 million and 30 million dollars.

Despite the fact that the USA continues dominating in the structure of issuers of the green bond market, the geographical diversification is increasing annually. Since 2015, the share of the USA among new issues has decreased from $47 \%$ to $34 \%$, of Sweden - from $10 \%$ to $7 \%$, of France - from $11 \%$ to $3 \%$, while the share of other developed countries, including Canada, the Netherlands, Germany, the United Kingdom, etc.from $32 \%$ to $25 \%$.

At the same time, financial institutions of India and Mexico entered the market, which issue share in 2017 was $19 \%$, as well as China with a share of $6 \%$. This trend marks the development of the green bond market on a global scale.

It is also necessary to highlight the diversification of funded projects. In 2016 among all the issues 38\% of the funds were used to finance projects in the field of alternative energy and $21 \%$ to finance projects to increase energy efficiency, and in 2017 their shares were 33\% and $29 \%$.
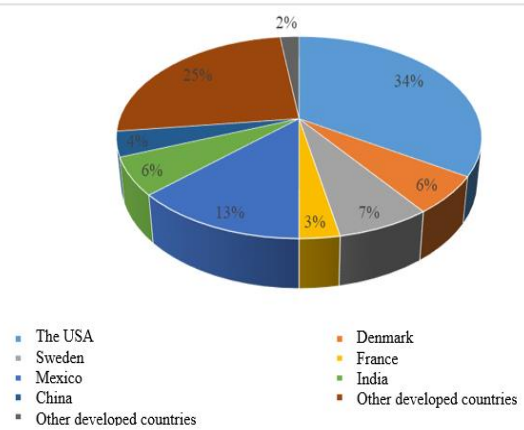

Fig. 6. The structure of the green bond issues in 2017 among countries in \% [9]

Despite the fact that the renewable energy remains the most popular destination, its share is decreasing, while funds raised for energy efficiency increased 2.4 times in 2017. Areas such as waste management, sustainable use of land and forest resources and adaptation to climate change, amounted to about $11 \%$ in total against $12 \%$ in 2017 . Such share is explained by 
risks associated with climate change and environmental pollution;

environmental due to the lack of exact generally accepted definitions and criteria for identifying the effect of individual measures on specific positive changes in the field of sustainable development.

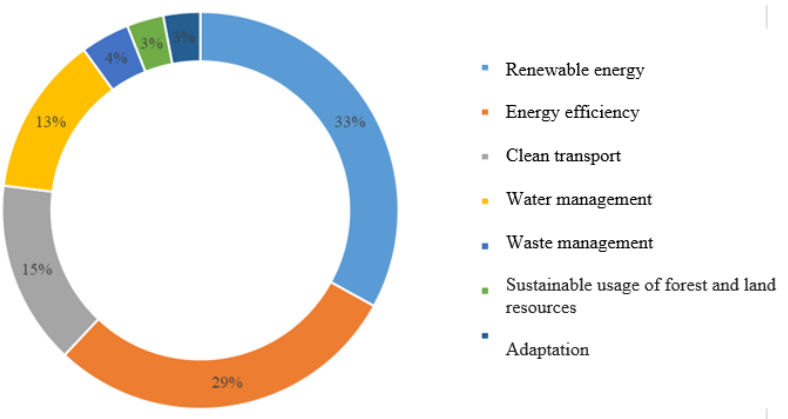

Fig. 7. The structure of the green bond issues by funded projects in 2017 , in $\%[2]$

For the beginning of 2018, 145 European companies issued green bonds (about a third part of the world volume) in various forms, volumes and with different maturities, which indicate a significant diversification of the market of green bonds in Europe [10]. The size of bond issues varies from large bank issues of more than 1 billion euros to relatively small issues - less than 100 million euros - by the representatives of the government and private business. Energy companies, financial institutions, real estate companies, local governments issue the green bonds in general, but there is also a large potential for developing corporate equity issues, especially in such countries like the United Kingdom, Germany and France [11].

The power sector remains at the leading position among the areas where funds raised from issuing bonds are directed, although in recent years its share in the overall structure has decreased, with an increase in the share of the construction and transport sectors. According to the terms of maturity today, bonds with 10-year or less maturity prevail in Europe (70\% of all issued green bonds).

The largest green bond market in Europe is the French market (the green bond issue for the period from 2012 to the first quarter of 2018 is 37.8 billion euros), then there are German markets (22.6 billion euros), The Netherlands (13.0 billion euros) and Sweden (10.9 billion euros). The French green bond market has one of the highest levels of transparency, and its further growth is possible by increasing emissions from companies focused on a particular product or service and government agencies.

The markets of the Scandinavian countries are characterized by small volumes of emissions of green bonds, but have a significant number of such issues [11].

Today, green bonds represent about $1 \%$ of the total global debt market. This segment is developing fast, and a number of factors will support this dynamics in future:

- There has been a significant transformation in fact, how businesses, customers and investors perceive the
- Technological progress increases the price competitiveness of low-carbon technologies, including renewable energy sources and electric vehicles, in comparison with traditional ones. Green investments began to bring business and investors not only ethical, but also financial benefits;

- The financial institutions of China and India, issuing green bonds in 2015 for the first time, supported efforts to green industry in developing countries with their authority, and also made significant diversity in the market, where only developed countries dominated (mainly the United States, United Kingdom and Scandinavian countries due to the implementation of large-scale projects in the field of alternative energy).

\section{DISCUSSION}

Summing everything up, it is necessary to highlight that the market for green financing is currently a rapidly growing and promising segment of the global financial market (Fig. 8). So, to the mid-2017:

- the green bond market amounted to more than $\$ 150$ billion;

- the entire market for "climate" securities - about $\$ 700$ billion [6];

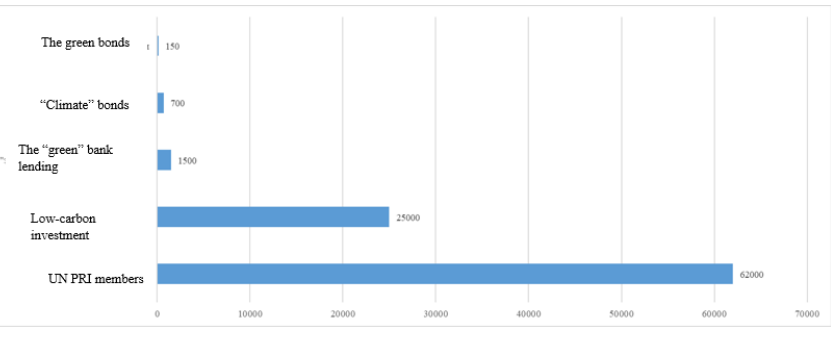

Fig. 8. Market volume of green financing, billion US dollars $[9,13]$

- bank green loans and government funding are about 11.5 trillion USD according to various estimates [5];

- more than 400 institutional investors, whose management is more than 25 trillion US dollars stick to the principles of low carbon investment;

- 1.5 thousand members of the UN Principles for Responsible Investment (UN PRI) manage assets totally more than 62 trillion USD [13].

According to researches, at least 93 trillion US dollars should be directed to green projects by 2030 . According to the International Energy Agency, the total investment in energy capacity (including energy efficiency) on the same date is about 53 trillion US dollars. Among them 18 trillion US dollars will go for Asia and Oceania [1].

The development of the green finance market is an objective process that coincided with global reforms and promoted by them, and the new stage in the development of 
development of public-private partnerships to spread high costs associated with "green" issue; promotion of the sustainable development goals and instruments of responsible Finance.

\section{REFERENCES}

[1] D.E. Grigoriev, On the "green" financial instruments http://www.mnr.gov.ru/docs/gr_19052017.pdf .

[2] M. Flaherty, A. Gevorkyan, S. Radpour, W. Semmler, "Financing climate policies through climate bonds- a three stage model and empirics," Research in International Business and Finance, New York: Schwartz Center for Economic Policy Analysis (SCEPA), 2017, pp. 470.

[3] C. MacKenzie, F. Ascui, "Investor leadership on climate change: an analysis of the investment community's role on climate change, and snapshot of recent investor activity," United Nations Global Compact URL:

[4] B.B. Rubtsov, I.A. Gusev, A.I. Ilyinsky, I.V. Lukashenko, S.A. Panova, A.F. Sadretdinova, S.M. Alykova, B.B. Rubtsov, "Green finance" in the world and in Russia: monograph, 2016, pp. 170.

[5] Green Bonds in the CBonds database / / financial and information Agency CBonds. URL: http://ru.cbonds.info/news/item/754195/.

[6] Green bonds soar to record \$163bn in 2017 // Reneweconomy.com. 2018.URL: https://reneweconomy.com.au/ graph-day-green-bonds-soarrecord-163bn- 2017.

The article proposes an algorithm for step-by-step investment support for "clean" transport infrastructure projects, taking into account the life cycle of the transport project, including the use of public - private partnership tools; an approach to evaluating the effectiveness of investment support for the construction and operation project with the participation of "green" financing. Effective use of the proposed scheme requires further development of national standards for "green" financial instruments. At the same time, the article proves that environmental initiatives require a significant amount of financial resources that need to be accumulated, including using various financial tools of debt and equity financing. Despite the measures to implement the principles of responsible financing, which are held in the Russian economy (budget, reimbursement to the Issuer of $70 \%$ $-90 \%$ of coupon payments to investors, preferential rates on loans, compensation of expenses for verification and monitoring of "green" status of the securities), determined by the concerted phases of the project life cycle algorithm of its funding.

The proposed algorithm allows one to synchronize the real and financial sectors of the economy, reduce investment lags of reproduction processes in "green" projects.

The study identified the main challenges for the development of eco-bonds that need to be addressed in the development of national standards of "green" financial instruments: legal regulation of the market of "green" securities; the targeting of benefits for issuers; the
[7] I.N. Bazhenov, "Green financing: global trends and Russian practice," Problems of the National Strategy, vol. 5(50), 2018, pp.172-184

[8] https://www.unglobalcompact.org/docs/issues_doc/Environment/Investo r_Leadership_on_Climate_Change_An_Analysis.pdf.

[9] Green Bonds Highlights 2017 // Climate Bonds Initiative. URL: https://www.climatebonds.net.

[10] European green bond market URL: https://roscongress.org/materials/evropeyskiy-rynok-zelyenykhobligatsiy-2018/.

[11] Principles for Responsible Investment. URL: https://www.unpri.org.

[12] G20 Green Finance Study Group G20 Green Finance Synthesis Report, 15.07.2016 https://www.unepinquiry.org.

[13] Mobilising Bond Markets for a Low-Carbon Transition// OECD. Official website. 2017. 19 April. URL: http://www.oecd.org.

[14] The Green Bond Market in Europe 2018. URL: https://www.climatebonds.net/files/reports/the_green_bond_market_in_ europe.pdf .

[15] Hao Zhang, Regulating green bond in China: definition divergence and implications for policy making // Journal of Sustainable Finance \&Investment,2019.URL:https://www.tandfonline.com/doi/full/10.1080/2 0430795.2019.1706310.

[16] J. Banga, "The green bond market: a potential source of climate finance for developing countries," Journal of Sustainable Finance \& Investment, vol. 9(1), 2019, pp. 17-32.

[17] Study on the potential of green bond finance for resource-efficient investments https://ec.europa.eu/environment/enveco/pdf/potentialgreen-bond.pdf .

[18] A. Causevic, S. Selvakkumaran, "The role of multilateral climate funds in urban transitions between 1994 and 2014", Journal of Sustainable Finance \& Investment, vol. 8(1), 2018, pp. 275-299. 